\title{
Pulsing With Low Concentration Gibberellin Plus Benzyladenine or Commercial Floral Preservatives Affect Postharvest Longevity, Quality, and Leaf Chlorosis of Cut Lilies and Gladioli
}

\author{
Iftikhar Ahmad $^{1,2,4}$, John M. Dole ${ }^{1}$, and Bruno T. Favero ${ }^{1,3}$
}

\begin{abstract}
ADDITIONAL INDEX WORDs. plant growth regulators, senescence, vase life
SUMMARY. Effects of pulsing with different concentrations of gibberellin plus benzyladenine $\left(\mathrm{GA}_{4+7}+\mathrm{BA}\right)$, a proprietary mixture of $\mathrm{GA}_{4+7}$ plus $\mathrm{BA}$ in a commercial floral preservative $\left(\mathrm{GA}_{4+7}+\mathrm{BA}+\right.$ preservative $)$, or a propriety mixture of sugar plus acidifier developed for bulbous flowers (floral bulb preservative) were studied on postharvest performance and quality of cut lily (Lilium hybrids) and gladiolus (Gladiolus hybrids) flowers. Pulsing of cut stems of lily with $\mathrm{GA}_{4+7}+\mathrm{BA}$ at 5 or $2 \mathrm{~mL} \cdot \mathrm{L}^{-1} \mathrm{GA}_{4+7}+\mathrm{BA}+$ preservative for 20 hours at $3 \pm \mathbf{1}^{\circ} \mathrm{C}$ extended the vase life and controlled leaf chlorosis of 'Cobra' oriental lily and 'Cappuccino' and 'Dot Com' asiatic lily. Cut 'Orange Art' asiatic lily performed best when pulsed with $\mathrm{GA}_{4+7}+\mathrm{BA}$ at $10 \mathrm{mg} \cdot \mathrm{L}^{-1}$. For cut gladiolus, pulsing with $\mathrm{GA}_{4+7}+\mathrm{BA}$ at $10 \mathrm{mg} \cdot \mathrm{L}^{-1}$ extended the vase life of 'Alice', 'Mammoth', and 'Passion', while 'Scarlet' had the longest vase life when pulsed with $\mathbf{5} \mathbf{~ m g} \cdot \mathrm{L}^{-1}$ $\mathrm{GA}_{4+7}+\mathrm{BA}$. $\mathrm{GA}_{4+7}+\mathrm{BA}+$ preservative also extended the vase life and controlled leaf chlorosis, but the floral bulb preservative had no effect on vase life extension or preventing leaf chlorosis of lilies. Gladiolus cultivars had no or minor leaf chlorosis during vase period. Overall, overnight pulsing with $\mathrm{GA}_{4+7}+\mathrm{BA}$ or $\mathrm{GA}_{4+7}+\mathrm{BA}+$ preservative extended the vase life and prevented leaf chlorosis and can be used by growers and wholesalers for maintaining quality of cut stems.
\end{abstract}

L

ilies and gladioli are among the most important cut flowers grown throughout the world. However, leaf chlorosis is a major postharvest disorder that can limit their vase life. The chlorosis starts on lower leaves and proceeds upward, reducing stem quality and causing early senescence. This problem is accentuated by shipping or cold storage, resulting in early leaf wilting or abscission (Han, 2001). But storage or shipping at low

This research was funded by the Joseph $\mathrm{H}$. Hill Memorial Foundation, Inc., and International Cut Flower Growers Association.

Authors are grateful to The Sun Valley Group, Arcata, $\mathrm{CA}$, for providing lily stems and Glad-A-Way Gardens, Santa Maria, CA, for providing gladiolus stems for the study. We would also like to thank Gayle Smith, Technical Consulting Manager, Chrysal Americas, for Chrysal products and Dr. Brian Whipker for provision of Fresco for the study.

Use of trade names in this publication does not imply endorsement by the USDA or NCARS of products named nor criticism of similar ones not mentioned.

${ }^{1}$ Department of Horticultural Science, North Carolina State University, Raleigh, NC 27695

${ }^{2}$ Institute of Horticultural Sciences, University of Agriculture, Faisalabad 38040, Pakistan

${ }^{3}$ Instituto de Biociencias, Universidad Estadual Paulista (USESP), Botucatu, Sao Paolo, Brazil

${ }^{4}$ Corresponding author. E-mail: iftikharahmadhashmi@ gmail.com. temperatures is necessary for transportation and marketing of cut stems to distant markets. Fluctuations in temperature during shipping/storage or transit time greatly affect cut lilies and loss of quality starts quickly when stems are placed in the retail or consumer environment after transit/storage. Additionally, cultivars vary in exhibiting leaf chlorosis symptoms (Leonard et al., 1998).

Use of gibberellins and cytokinins effectively controlled leaf chlorosis of calla lily [Zantedeschia aethiopica (Skutnik et al., 2001)], narcissus [ Narcissus tazetta (Ichimura and Goto, 2000)], goldenrod [Solidago canadensis (Philosoph-Hadas et al., 1996)], and alstroemeria [Alstroemeria sp. (Hicklenton, 1991)]. Continuous vase application at 0.5 and $2.5 \mathrm{mg} \cdot \mathrm{L}^{-1}$ each of gibberellin and cytokinin or shortterm 4 -h pulse at $25 \mathrm{mg} \cdot \mathrm{L}^{-1}$ controlled leaf chlorosis of cut oriental and asiatic lilies. However, continuous application enhanced bud blasting (Han, 2001). Similarly, mode and time of application of PGR also affected leaf chlorosis of lilies and various cultivars of potted oriental hybrid lily or easter lily (Lilium longiflorum) responded differently, depending on the mode of application (Çelikel et al., 2002; Han, 1997; Ranwala and Miller, 2000). Several commercial formulations of gibberellin plus benzyladenine have also been tested for preventing leaf chlorosis, such as Provide or Promalin (Abbot Chemical Co., North Chicago, IL) and Fascination (Valent BioSciences Corp., Libertyville, IL) (Han, 1997, Leonard and Nell, 2004). Gibberellin controlled leaf chlorosis more effectively than just benzyladenine (van Doorn and Han, 2011). Among commercial floral preservative products, a proprietary mixture of $\mathrm{GA}_{4+7}$ plus BA in a commercial floral preservative (Chrysal BVB; Chrysal, Miami, FL) controlled leaf chlorosis of lilies, but a proprietary mixture containing gibberellin (Chrysal SVB), did not (Leonard and Nell, 2004). However, the proprietary mixture containing gibberellin was effective for prevention of leaf chlorosis in christmas bells [Sandersonia aurantica (Eason, 2002)].

Although several studies on use of different concentrations and application methods of gibberellins and cytokinin have been conducted on cut lilies to control leaf chlorosis, limited information has been reported on pulsing at low concentrations under low temperature used commercially for transportation or storage of cut lilies. Moreover, to our knowledge, no study is reported on effect of gibberellins and benzyladenine on postharvest performance of cut gladiolus. Therefore, the objectives of this

\begin{tabular}{llll}
\hline $\begin{array}{l}\text { Units } \\
\text { To convert U.S. to SI, } \\
\text { multiply by }\end{array}$ & U.S. unit & SI unit & $\begin{array}{l}\text { To convert SI to U.S., } \\
\text { multiply by }\end{array}$ \\
\hline 29.5735 & $\mathrm{fl} \mathrm{oz}$ & $\mathrm{mL}$ & 0.0338 \\
1 & $\mathrm{mmho} / \mathrm{cm}$ & $\mathrm{dS} \cdot \mathrm{m}^{-1}$ & 1 \\
28.3495 & $\mathrm{oz}$ & $\mathrm{g}$ & 0.0353 \\
1 & $\mathrm{ppm}$ & $\mathrm{mg} \cdot \mathrm{L}^{-1}$ & 1 \\
0.001 & $\mathrm{ppm}$ & $\mathrm{mL} \cdot \mathrm{L}^{-1}$ & 1000 \\
$\left({ }^{\circ} \mathrm{F}-32\right) \div 1.8$ & ${ }^{\circ} \mathrm{F}$ & ${ }^{\circ} \mathrm{C}$ & $\left({ }^{\circ} \mathrm{C} \times 1.8\right)+32$
\end{tabular}


study were to evaluate the effects of a new plant growth regulator proprietary product, $\mathrm{GA}_{4+7}+\mathrm{BA}$ (Fresco; Fine Americas, Walnut Creek, CA), on leaf chlorosis and vase life extension, and to compare the effects of different concentrations of $\mathrm{GA}_{4+7}+$ BA with $\mathrm{GA}_{4+7}+\mathrm{BA}+$ preservative or a propriety mixture of sugar plus acidifier developed for bulbous flowers [floral bulb preservative (Chrysal Bulb Flower Food)] on postharvest quality and leaf chlorosis of cut lilies and gladioli.

\section{Materials and methods}

Plant material. Cut stems of lilies and gladiolus were received from The Sun Valley Group, Arcata, CA, and Glad-A-Way Gardens, Santa Maria, CA, respectively, during Oct. to Nov. 2013 at the Postharvest Laboratory, Department of Horticultural Science, North Carolina State University (NCSU), Raleigh. Stems of 'Cobra' oriental hybrid lily, 'Cappuccino', 'Dot Com', and 'Orange Art' asiatic hybrid lily, and 'Alice', 'Mammoth', 'Passion', and 'Scarlet' gladiolus were harvested in California in the morning when no flowers/florets were opened, hydrated in water, packed dry in standard floral boxes without any further treatment, and transported to the NCSU laboratory within $4 \mathrm{~d}$ of harvest. On arrival, stems were sorted into uniform groups on the basis of number of opened florets and stem caliper, labeled, recut to 60 or $80 \mathrm{~cm}$ lengths for lilies or gladioli, respectively, and placed in respective pulsing solutions. Solutions included $\mathrm{GA}_{4+7}+\mathrm{BA}$ at 2.5, 5.0 , or $10.0 \mathrm{mg} \cdot \mathrm{L}^{-1}$ or commercial preservatives, $\mathrm{GA}_{4+7}+\mathrm{BA}+$ preservative at $2 \mathrm{~mL} \cdot \mathrm{L}^{-1}$ or floral bulb preservative at $10.0 \mathrm{~g} \cdot \mathrm{L}^{-1} \cdot \mathrm{GA}_{4+7}+\mathrm{BA}+$ preservative was not tested on 'Scarlet' gladiolus. All solutions were prepared using tap water $[\mathrm{pH} 7.3$, electrical conductivity (EC) $0.26 \mathrm{dS} \cdot \mathrm{m}^{-1}$ ], which was also used as control without any added compound. All solutions and stems were placed at $3 \pm 1^{\circ} \mathrm{C}$ in dark for $20 \mathrm{~h}$. Thereafter, stem ends were rinsed in water and stems were placed in vases containing $700 \mathrm{~mL}$ tap water ( $\mathrm{pH} 7.4$, EC $\left.0.25 \mathrm{dS} \cdot \mathrm{m}^{-1}\right)$, with three stems per vase at $21 \pm 1^{\circ} \mathrm{C}$ with $40 \%$ to $60 \%$ relative humidity and a $12 \mathrm{~h}$ photoperiod provided by cool-white fluorescent lamps with a photosynthetic photon flux of about $20 \mu \mathrm{mol} \cdot \mathrm{m}^{-2} \cdot \mathrm{s}^{-1}$ as measured at bench level with a quantum light meter (1078 QMSW; Apogee Instruments, Logan, UT).

Measurements. Data were collected daily for vase life (duration from placement of stems in vases in the postharvest evaluation room to the time when individual stems ended), change in fresh weight (on day 6 of vase life), stem quality (rated on a scale of $1-10$ on day 6 of vase life, where $1=0 \%$ to $10 \%$ wilting, chlorosis, or discoloration, and $10=91 \%$ to $100 \%$ wilting, chlorosis, or discoloration), water uptake (up until when first stem was ended in entire experiment), number of opened flowers during vase period, number of yellow leaves at termination, and termination symptoms. Symptoms for terminations were recorded as either present or not, and included leaf or petal abscission, necrosis, or wilting for lilies, and bent stem, bluing, leaf tip chlorosis, petal necrosis or wilting, or sepal chlorosis for gladiolus. The condition was recorded as present if it occurred on at least one petal/floret, bud, leaf, or stem, and stems were ended when they developed one or more of the aforementioned symptoms on $\geq 50 \%$ of the flowers/inflorescence, foliage, or stem (Ahmad et al., 2013).

Statistical analyses. All experiments were completely randomized designs with five replicate vases of three stems each. Data were subjected to analysis of variance procedures using General Linear Models procedures of SAS (version 9.3; SAS Institute, Cary, NC) and means were separated using Fisher's least significant difference at $P \leq 0.05$. Experiments were also repeated for 'Cobra' and 'Orange Art' lily and for 'Mammoth', 'Passion', and 'Scarlet' gladiolus for confirmation of results. However, data were presented for only one experiment for each cultivar due to similar results among experiments.

\section{Results and discussion}

Lily. Stems of 'Cobra' oriental hybrid lily and 'Cappuccino' and 'Dot Com' asiatic hybrid lily had longest vase lives when pulsed with 5 or 10 $\mathrm{mg} \cdot \mathrm{L}^{-1} \mathrm{GA}_{4+7}+\mathrm{BA}$ or $\mathrm{GA}_{4+7}+\mathrm{BA}+$ preservative (Table 1). For 'Orange Art' asiatic hybrid lily, use of $\mathrm{GA}_{4+7}+$ $\mathrm{BA}$ at $10 \mathrm{mg} \cdot \mathrm{L}^{-1}$ or $\mathrm{GA}_{4+7}+\mathrm{BA}+$ preservative resulted in longest vase life. Moreover, both compounds effectively controlled leaf yellowing of 'Cobra', 'Dot Com', and 'Orange Art' lily, and considerably reduced leaf yellowing of 'Cappuccino' lily. Results highlighted the efficacy of pulsing with $\mathrm{GA}_{4+7}+\mathrm{BA}+$ preservative or $\mathrm{GA}_{4+7}+$ BA for maintaining stem quality and reducing loss of stem fresh weight during vase period. Use of gibberellins and benzyladenine is reported to control leaf chlorosis in easter lily (Han, 1997; Whitman et al., 2001), potted oriental lily (Çelikel et al., 2002; Ranwala and Miller, 2000), and cut lilies (Han, 2001; van Doorn and Han, 2011). However, continuous vase application at 0.5 or $2.5 \mathrm{mg} \cdot \mathrm{L}^{-1}$ or pulse at $25 \mathrm{mg} \cdot \mathrm{L}^{-1}$ for $4 \mathrm{~h}$ increased bud abscission (Han, 2001). Therefore, use of lower concentration of 5-10 $\mathrm{mg} \cdot \mathrm{L}^{-1}$ for $20 \mathrm{~h}$ in this study provided a better option to control leaf chlorosis without any negative effects. In this study, $\mathrm{GA}_{4+7}+\mathrm{BA}$ and $\mathrm{GA}_{4+7}+\mathrm{BA}+$ preservative either increased or had no effect on the number of flowers opening. Leonard and Nell (2004) also noted that $\mathrm{GA}_{4+7}+\mathrm{BA}+$ preservative was effective for controlling leaf chlorosis and vase life extension of oriental lilies.

Pulsing with floral bulb preservative produced a similar vase life as with tap water, except for 'Dot Com' where vase life was $1.7 \mathrm{~d}$ longer for floral bulb preservative than tap water (Table 1). Stems for all cultivars in tap water gained the least fresh weight (FW) or lost the most FW at day 6. Pulsing with floral bulb preservative increased water uptake of 'Orange Art', but reduced uptake in 'Cappuccino' lily. Floral bulb preservative was intended as a final product to be used in vases and did not provide good results as a short-term pulsing solution.

Most common symptoms for termination of stems included abscission, necrosis, or wilting of leaves or petals with treatments significantly affecting leaf wilting and petal abscission for most cultivars (Table 1 ). Stems pulsed with tap water or floral bulb preservative resulted in the least petal abscission for all cultivars and the most leaf wilting with 'Cappuccino', 'Dot Com', and 'Orange Art'. In addition, 5 or $10 \mathrm{mg} \cdot \mathrm{L}^{-1} \mathrm{GA}_{4+7}+$ $\mathrm{BA}$ or $\mathrm{GA}_{4+7}+\mathrm{BA}+$ preservative also resulted in higher leaf abscission in 'Cobra' ( $13 \%$ to 33\%), higher leaf necrosis in 'Dot Com' ( $40 \%$ to $87 \%$ ) and higher petal necrosis in 'Dot Com' 
Table 1. Effect of gibberellin plus benzyladenine $\left(\mathrm{GA}_{4+7}+\mathrm{BA}\right)$, a commercial proprietary floral preservative mixture of $\mathrm{GA}_{4+7}$ plus BA $\left(\mathrm{GA}_{4+7}+\mathrm{BA}+\right.$ preservative), or a commercial proprietary floral preservative mixture of sugar plus acidifier for bulbous flowers (floral bulb preservative) on vase life and postharvest parameters of 'Cobra' oriental lily and 'Cappuccino', 'Dot Com', and 'Orange Art' asiatic lily. Data for fresh weight change represent means of five replicate stems, for water uptake represent five replicate vases, whereas all other data represent means of 15 stems with three stems per vase.

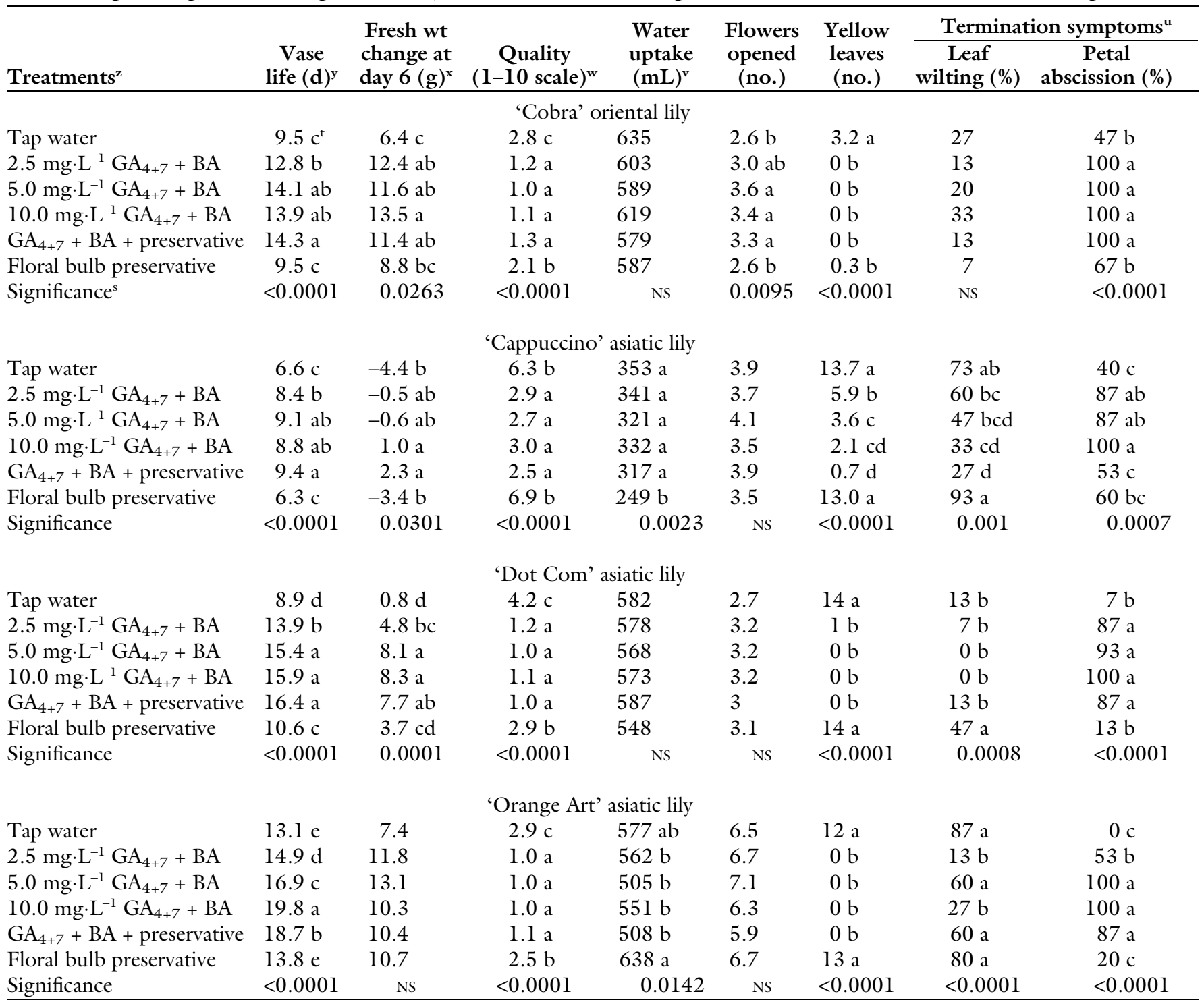

${ }^{2} \mathrm{lmg} \cdot \mathrm{L}^{-1}=1 \mathrm{ppm}$.

${ }^{y}$ Days from placing stems in vases in vase life evaluation room until termination.

${ }^{x}$ Final value minus initial value; $1 \mathrm{~g}=0.0353 \mathrm{oz}$.

${ }^{\mathrm{w}} \mathrm{Q}$ uality was rated on day 6 of vase life on a scale $1-10$, where $1=0 \%$ to $10 \%$ wilting, chlorosis, or discoloration and $10=91 \%$ to $100 \%$ wilting, chlorosis, or discoloration. ${ }^{\mathrm{V}} \mathrm{l} \mathrm{mL}=0.0338 \mathrm{fl} \mathrm{oz}$.

"Percentage of stems in a treatment exhibiting symptoms.

${ }^{t}$ Mean separation within columns for each cultivar by Fisher's least significant difference at $P \leq 0.05$

sProbability values were obtained using General Linear Models (GLM) procedures (version 9.3; SAS Institute, Cary, NC); NS = nonsignificant at $P>0.05$.

(73\% to $100 \%)$ compared with tap water $(0 \%, 7 \%$, and $13 \%$, respectively) (data not presented). The higher rate of leaf and petal abscission and necrosis for $\mathrm{GA}_{4+7}+\mathrm{BA}$ or $\mathrm{GA}_{4+7}+\mathrm{BA}+$ preservative treated flowers is likely due to the longer vase life. Other reports indicated that cut lily stems generally senesce due to leaf chlorosis or petal wilting (van Doorn and Han, 2011). Additionally, bud abscission, petal abscission or browning, or failure of buds to open also result in rapid loss of quality in some cultivars. In the current studies, none of the cultivars had abscised buds. Incidence of leaf abscission was relatively low in the cultivars varying from $0 \%$ for 'Cappuccino', 'Dot Com', and 'Orange Art' to $11 \%$ for 'Cobra', while leaf necrosis incidence ranged from $0 \%$ for 'Cobra' to $55 \%, 31 \%$, and $65 \%$ for 'Cappuccino', 'Dot Com', and 'Orange Art', respectively. Incidence of petal wilting was $100 \%$ in all of the cultivars.

Gladiolus. Cut stems of 'Alice', 'Mammoth', 'Passion', and 'Scarlet' gladiolus had longest vase life, when pulsed with 5 or $10 \mathrm{mg} \cdot \mathrm{L}^{-1} \mathrm{GA}_{4+7}+$ BA (Table 2). Gladiolus stems had no or minor leaf yellowing with a significant difference found only for 'Alice' in which stems pulsed with $\mathrm{GA}_{4+7}+$ BA had less leaf yellowing. Stems of 'Alice', 'Passion', and 'Scarlet' pulsed 
Table 2. Effect of gibberellin plus benzyladenine $\left(\mathrm{GA}_{4+7}+\mathrm{BA}\right)$, a commercial proprietary floral preservative mixture of $\mathrm{GA}_{4+7}$ plus BA $\left(\mathrm{GA}_{4+7}+\mathrm{BA}+\right.$ preservative), or a commercial proprietary floral preservative mixture of sugar plus acidifier for bulbous flowers (floral bulb preservative) on vase life and postharvest parameters of 'Alice', 'Mammoth', 'Passion', and 'Scarlet' gladiolus. $\mathrm{GA}_{4+7}+\mathrm{BA}+$ preservative was not tested on 'Scarlet'. Data for fresh weight change represent means of five replicate stems, for water uptake represent five replicate vases, whereas all other data represent means of 15 stems with three stems per vase.

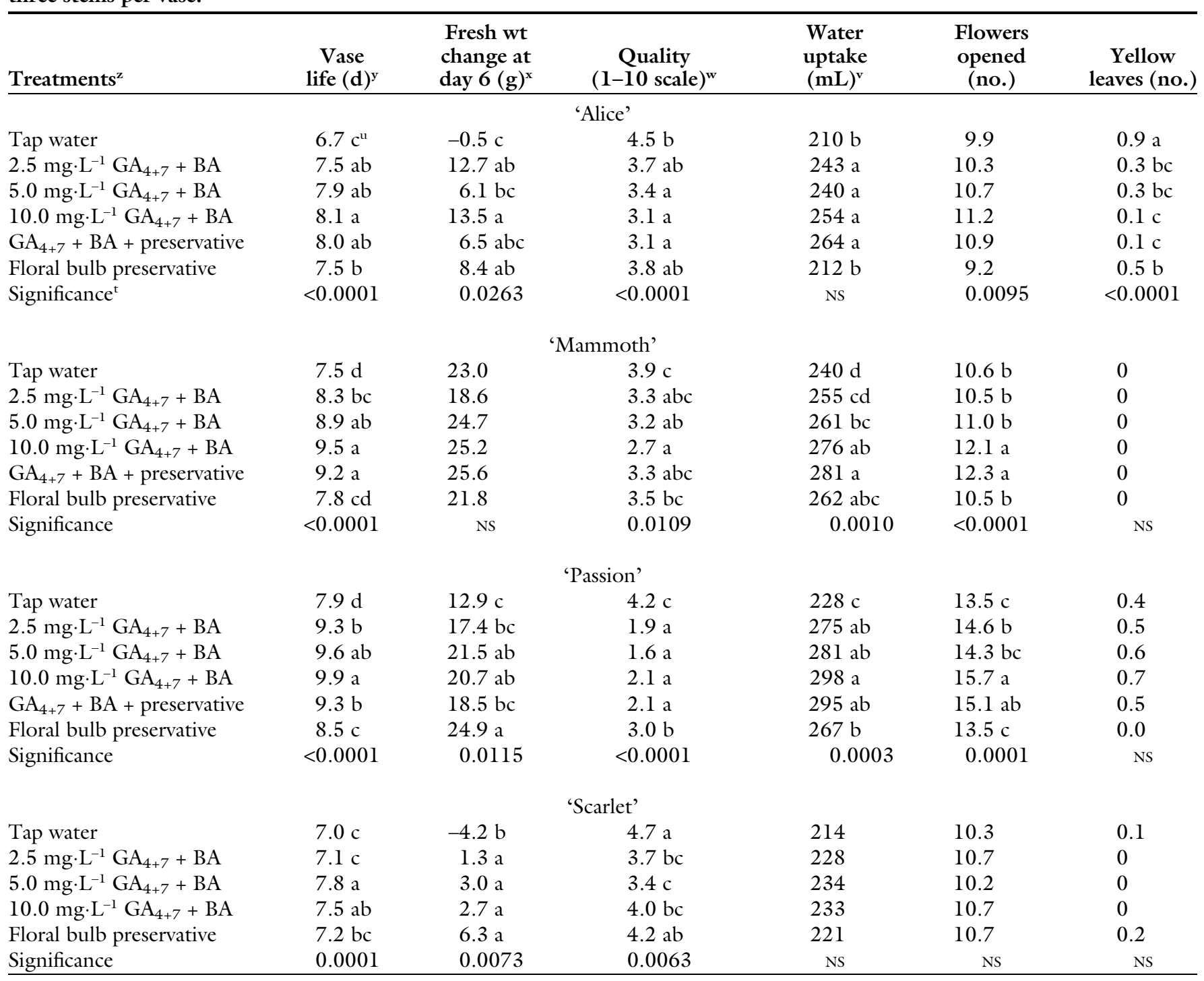

${ }^{\mathrm{z}} \mathrm{l} \mathrm{mg} \cdot \mathrm{L}^{-1}=1 \mathrm{ppm}$.

yays from placing stems in vases in vase life evaluation room until termination.

${ }^{\mathrm{x}}$ Final value minus initial value; $1 \mathrm{~g}=0.0353 \mathrm{oz}$.

"Quality was rated on day 6 of vase life on a scale $1-10$, where $1=0 \%$ to $10 \%$ wilting, chlorosis, or discoloration and $10=91 \%$ to $100 \%$ wilting, chlorosis, or discoloration. " $1 \mathrm{~mL}=0.0338 \mathrm{fl} \mathrm{oz}$.

"Mean separation within columns for each cultivar by Fisher's least significant difference at $P \leq 0.05$.

tProbability values were obtained using General Linear Models (GLM) procedures (version 9.3; SAS Institute, Cary, NC); NS = nonsignificant at $P>0.05$.

with $\mathrm{GA}_{4+7}+\mathrm{BA}$ had higher FW gain than stems pulsed with tap water. Quality was also higher for all cultivars and water uptake was higher for all cultivars, but Scarlet when pulsed with 5 or $10 \mathrm{mg} \cdot \mathrm{L}^{-1} \mathrm{GA}_{4+7}+\mathrm{BA}$ compared with stems pulsed with tap water. More flowers opened on 'Alice', 'Mammoth', and 'Passion' when treated with $10 \mathrm{mg} \cdot \mathrm{L}^{-1} \mathrm{GA}_{4+7}+$ BA than with tap water. Vase life extension in gladiolus cultivars due to pulsing with $\mathrm{GA}_{4+7}+\mathrm{BA}$ was smaller than the increase in vase life of lilies tested and most of the gladiolus cultivars used in the study had no major postharvest leaf-yellowing problem. Pulsing with $\mathrm{GA}_{4+7}+\mathrm{BA}$ improved stem quality, water uptake, and flower opening, which may be further extended if stems would be pulsed immediately after harvest.

Use of $\mathrm{GA}_{4+7}+\mathrm{BA}+$ preservative also extended the vase life of 'Alice', 'Mammoth', and 'Passion', but floral bulb preservative had no effect on
'Mammoth', 'Passion', and 'Scarlet' compared with tap water (Table 2). $\mathrm{GA}_{4+7}+\mathrm{BA}+$ preservative had a positive effect on most other measures as well: greater fresh weight change for 'Alice', higher stem quality for Alice' and 'Passion', higher water uptake for 'Alice', 'Mammoth', and 'Passion', greater flower opening for 'Mammoth and 'Passion', and reduced leaf yellowing for 'Alice'. Floral bulb preservative also had a positive effect, but less than $\mathrm{GA}_{4+7}+\mathrm{BA}+$ preservative: 
greater fresh weight change for 'Alice', 'Passion', and 'Scarlet', higher stem quality for 'Passion', higher water uptake for 'Mammoth', and reduced leaf yellowing for 'Alice' and 'Passion'. $\mathrm{GA}_{4+7}+\mathrm{BA}+$ preservative was developed as a grower-applied treatment to prevent leaf yellowing and promote flower opening, while floral bulb preservative was intended as final product to be used in vases. It is clear that the grower-applied pulsing treatment worked as intended, while the floral bulb preservative is probably better suited as a final solution.

Major reasons of termination of cut gladiolus stems were stem bending, petal necrosis or wilting, or sepal chlorosis, but most of the termination criteria were unaffected by the treatments (data not presented). Incidence of stem bending for 'Alice', 'Mammoth', 'Passion', and 'Scarlet' averaged $16 \%, 20 \%, 35 \%$, and $18 \%$, respectively, and incidence of sepal chlorosis averaged 88\%, 66\%, 77\%, and $0 \%$, respectively. For petal necrosis and wilt, $98 \%$ to $100 \%$ of stems exhibited the condition across all four cultivars. On the other hand, pulsing of 'Passion' gladiolus stems with $\mathrm{GA}_{4+7}+\mathrm{BA}$ or $\mathrm{GA}_{4+7}+\mathrm{BA}+$ preservative increased petal bluing incidence $(80 \%$ to $100 \%)$, which was not recorded for stems pulsed with tap water $(0 \%)$ or for the other cultivars. Petal blueing may have been a byproduct of increased vase life from $\mathrm{GA}_{4+7}+$ $\mathrm{BA}$ and $\mathrm{GA}_{4+7}+\mathrm{BA}+$ preservative. Pulsing with $\mathrm{GA}_{4+7}+\mathrm{BA}$ or $\mathrm{GA}_{4+7}+$ $\mathrm{BA}+$ preservative lowered the leaf tip chlorosis of 'Alice' ( $13 \%$ to $33 \%$ ) compared with tap water $(93 \%)$, which might be due to mobilization of carbohydrates to the opening petals. Movement of soluble sugars like sucrose between cells has been reported during senescence (Chuang and Chang, 2013). Leaf tip chlorosis was not noted on the other cultivars.

In summary, cut stems of lilies and gladioli should be pulsed with 5.0-10.0 $\mathrm{mg} \cdot \mathrm{L}^{-1} \mathrm{GA}_{4+7}+\mathrm{BA}$ or $2 \mathrm{~mL} \cdot \mathrm{L}^{-1} \mathrm{GA}_{4+7}+\mathrm{BA}+$ preservative at $3 \pm 1{ }^{\circ} \mathrm{C}$ in dark for $20 \mathrm{~h}$ before shipping for longest vase life and preventing leaf yellowing. However, floral bulb preservative was not effective as overnight pulse for vase life extension or controlling leaf yellowing. Commercial growers and wholesalers should consider maintaining postharvest quality of cut lilies and gladioli and increase financial returns by pulsing cut stems with $\mathrm{GA}_{4+7}+\mathrm{BA}$ or $\mathrm{GA}_{4+7}+\mathrm{BA}+$ preservative to control leaf yellowing in addition to vase life extension.

\section{Literature cited}

Ahmad, I., J.M. Dole, M. Saleem, M.A. Khan, A. Akram, and A.S. Khan. 2013. Preservatives and packaging material have an impact on the post-harvest longevity of cut Rosa bybrida L. 'Kardinal' flowers. J. Hort. Sci. Biotechnol. 88:251-256.

Celikel, F.G., L. Dodge, and M.S. Reid. 2002 . Efficacy of 1-MCP (1methylcyclopropene) and promalin for extending the post-harvest life of oriental lilies (Lilium $\times$ 'Mona Lisa' and 'Star Gazer'). Sci. Hort. 93:149-155.

Chuang, Y. and Y.A. Chang. 2013. The role of soluble sugars in vase solutions during the vase life of Eustoma grandiflorum. HortScience 48:222-226.

Eason, J.R. 2002. Sandersonia aurantiaca: An evaluation of postharvest pulsing solutions to maximize cut flower quality. N. Z. J. Crop Hort. Sci. 30:273-279.

Han, S. 1997. Preventing postproduction leaf yellowing in easter lily. J. Amer. Soc. Hort. Sci. 122:869-872.
Han, S. 2001. Benzyladenine and gibberellins improve postharvest quality of cut asiatic and oriental lilies. HortScience 36:741-745.

Hicklenton, P.R. 1991. GA 3 and benzylaminopurine delay leaf yellowing in cut Alstroemeria stems. HortScience 26: 1198-1199.

Ichimura, K. and R. Goto. 2000. Effect of gibberellin $\mathrm{GA}_{3}$ on leaf yellowing and vase life of cut Narcissus tazetta var. chinensis flowers. J. Jpn. Soc. Hort. Sci. 69:423427.

Leonard, R.T. and T.A. Nell. 2004. Short-term pulsing improves postharvest leaf quality of cut oriental lilies. HortTechnology 14:405-411.

Leonard, R.T., T.A. Nell, A.A. De Hertogh, and L. Gallitano. 1998. Lilies your customers will love. GrowerTalks 62:80-89.

Philosoph-Hadas, S., R. Michaeli, Y. Reuveni, and S. Meir. 1996. Benzyladenine pulsing retards leaf yellowing and improves quality of goldenrod (Solidago canadensis) cut flowers. Postharvest Biol. Technol. 9:65-73.

Ranwala, A.P. and W.B. Miller. 2000. Preventive mechanisms of gibberellin ${ }_{4+7}$ and light on low-temperature-induced leaf senescence of Lilium cv. Stargazer. Postharvest Biol. Technol. 19:85-92.

Skutnik, E., A. Lukaszewska, M. Serek, and J. Rabiza. 2001. Effect of growth regulators on postharvest characteristics of Zantedeschia aethiopica. Postharvest Biol. Technol. 21:241-246.

van Doorn, W.G. and S.S. Han. 2011. Postharvest quality of cut lily flowers. Postharvest Biol. Technol. 62:1-6.

Whitman, C.A., R.D. Heins, R. Meo, and K. Funnell. 2001. $\mathrm{GA}_{4+7}$ plus benzyladenine reduce foliar chlorosis of Lilium longiflorum. Sci. Hort. 89:143-154. 